\title{
Analisis Struktur Pori dan Sifat Mekanik Paduan Mg-0,5Ca-4Zn Hasil Proses Metalurgi Serbuk dengan Variasi Komposisi Foaming Agent $\mathrm{CaCO}_{3}$ dan Temperatur Sintering
}

\author{
Ika Kartika $^{1 *}$, Andi Mulya Ashari ${ }^{2}$, Adhitya Trenggono ${ }^{2}$, Franciska Pramuji Lestari $^{1}$, Aprilia Erryani ${ }^{1}$ \\ ${ }^{I}$ Pusat Penelitian Metalurgi dan Material - LIPI \\ Gedung 470, Kawasan Puspiptek Serpong, Banten, Indonesia 15310 \\ ${ }^{2}$ Teknik Metalurgi, Universitas Sultan Ageng Tirtayasa \\ Jl. Jenderal Sudirman KM.3 Cilegon, Banten, Indonesia 42435
}

\begin{abstract}
Abstrak
Paduan Mg-Zn-Ca dengan struktur berpori memiliki potensi sebagai implan mampu luruh yang dapat mengatasi persoalan dalam dunia medis. Tujuan studi ini adalah membuat paduan implan berpori $\mathrm{Mg}$ $0,5 \mathrm{Ca}-4 \mathrm{Zn}$ hasil proses metalurgi serbuk dengan variasi foaming agent $\mathrm{CaCO}_{3}$ dan temperatur sintering. Struktur pori yang dihasilkan dalam paduan dikarakterisasi dengan menggunakan x-ray diffraction (XRD) dan scanning electron microscopy (SEM). Persentasi porositas dalam paduan dilakukan dengan uji archimedes sesuai ASTM B311-93. Hasil identifikasi senyawa dalam paduan dengan XRD menunjukkan adanya fasa $\mathrm{Mg}, \mathrm{MgO}, \mathrm{MgZn}, \mathrm{Mg} \mathrm{Ca}_{2}$ dan fasa intermetalik $\mathrm{Ca}_{2} \mathrm{Mg}_{6} \mathrm{Zn}_{3}$. Semakin meningkatnya temperatur sintering dan penambahan $\mathrm{CaCO}_{3}$ dalam paduan meningkatkan pori yang terbentuk sehingga menurunkan densitas dan kekuatan tekan dari paduan Mg-0,5Ca-4Zn. Pengamatan dengan SEM menunjukkan ukuran pori terbesar yang terbentuk adalah sebesar 106,62 - 435,22 $\mu$ m yang dihasilkan dalam paduan $85,5 \mathrm{Mg}-0,5 \mathrm{Ca}-4 \mathrm{Zn}-10 \mathrm{CaCO}_{3}$ pada temperatur sintering $650{ }^{\circ} \mathrm{C}$.
\end{abstract}

Kata kunci: foaming agent $\mathrm{CaCO}_{3}$; paduan $\mathrm{Mg}-0,5 \mathrm{Ca}-4 \mathrm{Zn}$; proses metalurgi serbuk; implan mampu luruh; struktur berpori

\begin{abstract}
[Title: Pore Structure and Mechanical Properties Analysis of Alloys Mg-0,5Ca-4Zn Powder Metallurgy Process Result with Variation of $\mathrm{CaCO}_{3}$ Foaming Agent Composition and Sintering Temperature] Mg$\mathrm{Zn}$-Ca alloy with porous structure has the potential as a whole implant capable of overcoming problems in the medical world. The purpose of this study is to make an alloy of $\mathrm{Mg}-0.5 \mathrm{Ca}-4 \mathrm{Zn}$ porous implants resulting from the powder metallurgy process with variations of $\mathrm{CaCO}_{3}$ foaming agent and sintering temperature. The pore structure produced in the alloy is characterized by using $x$-ray diffraction $(X R D)$ and scanning electron microscopy (SEM). The percentage of porosity in the alloy was carried out by the archimedes test according to ASTM B311-93. The results of identification of compounds in the alloy with XRD showed the presence of $\mathrm{Mg}, \mathrm{MgO}, \mathrm{MgZn}, \mathrm{Mg}_{2} \mathrm{Ca}$ and intermetallic phase $\mathrm{Ca}_{2} \mathrm{Mg}_{6} \mathrm{Zn}_{3}$. Observation with SEM showed that the largest pore size formed was $106.62-435.22 \mu \mathrm{m}$ which was produced in an alloy of $85.5 \mathrm{Mg}-0.5 \mathrm{Ca}-4 \mathrm{Zn}-10 \mathrm{CaCO}_{3}$ at a sintering temperature of $650{ }^{\circ} \mathrm{C}$. Increasing the sintering temperature and $\mathrm{CaCO}_{3}$ in the alloy increases the pore formed thus reducing the density and compressive strength of the $\mathrm{Mg}-0.5 \mathrm{Ca}-4 \mathrm{Zn}$ alloy.
\end{abstract}

Keywords: $\mathrm{CaCO}_{3}$ foaming agent; $\mathrm{Mg}-0,5 \mathrm{Ca}-4 \mathrm{Zn}$ alloy; powder metallurgy process; bioresorbable implant; porous structure

\footnotetext{
${ }^{*}$ Penulis Korespondensi.

E-mail: ikak061001@gmail.com
}
1. Pendahuluan
Magnesium memiliki struktur kristal berupa hexagonal close packed (HCP), kondisi ini menyebabkan magnesium memiliki mampu bentuk yang




\section{TEKNIK, 40 (3), 2019, 143}

rendah pada temperatur kamar. Mekanisme yang digunakan dalam peningkatan sifat mekanik dalam magnesium dengan cara penguatan larutan padat (solid solution hardening), penguatan endapan (precipitation hardening) dan penguatan butiran (grain refinement hardening) (Radha \& Sreekanth, 2017). Paduan magnesium ada 3 jenis yaitu: (1) paduan Al (AZ91, AZ31), (2) paduan logam tanah jarang (AE21, WE43) dan (3) paduan tanpa $\mathrm{Al}$ (MgZn, $\mathrm{MgCa}, \mathrm{MgMn})$. Paduan tanpa alumunium banyak digunakan dalam aplikasi medis karena memiliki sifat biokompabilitas yang baik tanpa menimbulkan efek samping yang merugikan bagi tubuh (Sankalp $d k k$., 2016).

Seng $(\mathrm{Zn})$ adalah elemen yang sangat penting bagi nutrisi manusia setelah besi. Zn dalam tubuh manusia banyak ditemukan pada ginjal, hati, pankreas, jaringan, otot dan tulang. Unsur $\mathrm{Zn}$ juga merupakan salah satu material yang berpotensi paling baik untuk meningkatkan sifat mekanik dan ketahanan korosi dari paduan $\mathrm{Mg}$. Penambahan $\mathrm{Zn}$ ke dalam magnesium dapat memperhalus permukaan dan meningkatkan sifat mekanik seiring bertambahnya kandungan Zn (Zhang, Wang \& Geng, 2011; Zheng, Gu \& Witte, 2010; Xin $d k k$., 2008; Seyedraoufi \& Mirdamadi, 2013). Zn dapat meningkatkan kekuatan dan ductility magnesium dengan cara penguatan presipitasi. Zhang, Wang dan Geng (2011) meneliti paduan $\mathrm{Mg}-\mathrm{Zn}-\mathrm{Ca}$ dan menyimpulkan bahwa penambahan unsur Zn sebanyak $1-4 \%$ berat ke dalam magnesium dapat meningkatkan sifat mekanik. Akan tetapi, penambahan yang lebih dari itu akan menurunkan ketahanan korosi pada paduan magnesium. Seyedraoufi dan Mirdamadi (2013) meneliti paduan Mg$\mathrm{Zn}$ dan menyatakan bahwa $\mathrm{Zn}$ dapat memperhalus permukaan ukuran butiran Mg. Yang $d k k$. (2017) menyatakan bahwa penambahan $\mathrm{Zn}$ dapat memperhalus butiran paduan $\mathrm{Mg}-\mathrm{Zn}-\mathrm{Mn}$ hasil proses ekstrusi dan meningkatkan kekuatan tarik. Kayhan $d k k$. (2015) mempelajari pengaruh penambahan $3-6 \%$ berat $\mathrm{Zn}$ dalam matrik $\mathrm{Mg}-\mathrm{Ca}$ hasil cor dimana terjadi peningkatan ketahanan korosi seiring dengan meningkatnya penambahan $\mathrm{Zn}$.

Kalsium adalah elemen yang banyak ditemukan pada tulang manusia yang dapat mempercepat proses penyembuhan tulang manusia. Kalsium memiliki titik lebur pada temperatur $825{ }^{\circ} \mathrm{C}$ (Pulagara, Saini \& Dondapati, 2015). Kalsium memiliki densitas sebesar $1,55 \mathrm{~g} / \mathrm{cm}^{3}$ yang mirip dengan densitas magnesium sebesar $1,74 \mathrm{~g} / \mathrm{cm}^{3}$. Kalsium berfungsi sebagai agen penghalus butiran paduan magnesium dan penstabil ukuran butiran dengan penambahan lebih dari 0,5\% berat kalsium (Sankalp $d k k$., 2016). Paduan Mg-Ca menghasilkan fasa intermetalik $\mathrm{Mg}_{2} \mathrm{Ca}$ yang dapat mengurangi laju korosi. Zhang, Wang dan Geng (2012) mempelajari sifat korosi dari paduan $\mathrm{Mg}-\mathrm{Ca}$ dengan proses metalurgi serbuk. Selain itu, $\mathrm{Ca}$ dapat meningkatkan kuat regang, elongasi dan ketahanan korosi. Batas kelarutan kalsium dalam magnesium sebesar $1,34 \%$ berat. Kalsium yang terlarut dalam matriks magnesium dapat memperhalus butiran $\mathrm{Mg}$ dan meningkatkan kekuatan tanpa menurunkan elastisitas dari $\mathrm{Mg}$. Penambahan $\mathrm{Ca}$ lebih dari $1 \%$ berat dapat menimbulkan fasa intermetalik yang bersifat getas (Radha \& Sreekanth, 2017).

Logam berpori adalah logam yang menarik, yang mana terdiri dari beberapa kombinasi sifat mekanik, sifat konduktivitas, tahan panas dan daya serap bunyi yang baik. Metode pembuatan logam berpori dengan pori tertutup, yaitu melalui proses metalurgi serbuk dengan pencampuran foaming agent. Foaming agent dibutuhkan untuk menciptakan pori yang kasar pada paduan Mg-Zn-Ca. Mekanisme foaming agent yaitu dengan memanfaatkan temperatur dekomposisi untuk membuat busa sehingga material akan memiliki pori, sebelum penggunaan $\mathrm{CaCO}_{3}$ sebagai foaming agent, $\mathrm{TiH}_{2}$ sudah terlebih dahulu dikenal sebagai foaming agent untuk material berpori, akan tetapi penggunaan $\mathrm{TiH}_{2}$ memiliki kekurangan yaitu, biaya yang tinggi, resiko kebakaran, keracunan dan menghasilkan gas $\mathrm{H}_{2}$ (Gonzales, dkk., 2013). Pemilihan $\mathrm{CaCO}_{3}$ sebagai foaming agent lebih ekonomis, mendapatkan pori yang halus dan mudah mendapatkan keseragaman pori. $\mathrm{CaCO}_{3}$ akan terdekomposisi dan membentuk gas $\mathrm{CO}$ yang akan membentuk pori di dalam paduan $\mathrm{Mg}-\mathrm{Zn}-\mathrm{Ca}$ (Kennedy, 2012).

Dari penelitian sebelumnya dalam paduan $86 \mathrm{Mg}-\mathrm{Ca}-3 \mathrm{Zn}$ menggunakan $10 \%$ berat $\mathrm{CaCO}_{3}$ pada temperatur sintering $650{ }^{\circ} \mathrm{C}$ selama 10 dan 15 jam menunjukkan intensitas fasa $\mathrm{MgZn}$ lebih tinggi dibandingkan fasa $\mathrm{Mg}_{2} \mathrm{Ca}$ sehingga meningkatkan kekuatan mekanik dari paduan (Erryani $d k k ., 2017$ ). Dalam penelitian ini akan dipelajari pengaruh variasi foaming agent $\mathrm{CaCO}_{3}$ dan temperatur sintering terhadap distribusi dan ukuran pori dikaitkan dengan sifat mekanik yang diperoleh dari paduan berpori $\mathrm{Mg}-0,5 \mathrm{Ca}-4 \mathrm{Zn}$. Penambahan unsur $\mathrm{Ca}$ dan $\mathrm{Zn}$ serta penggunaan waktu tahan sintering selama 10 jam sebagai parameter pada studi terdahulu akan dijadikan acuan dalam studi ini untuk keberhasilan pengembangan proses pembuatan paduan berpori $\mathrm{MgCaZn}$.

\section{Bahan dan Metode}

Serbuk logam dari Merck yang digunakan dalam penelitian ini memiliki ketentuan : serbuk $\mathrm{Mg}$ (kemurnian 98,5\% ukuran partikel 0,06-0,3 mm), serbuk Zn (kemurnian 99\%, ukuran partikel <0,045 $\mathrm{mm}), \mathrm{Ca}$ granular (kemurnian 98\%) dan $\mathrm{CaCO}_{3}$ (kemurnian 98,96\%, ukuran partikel $<0,003 \mathrm{~mm}$ ). Ca masih berbentuk granular kasar, sehingga dibutuhkan 


\section{TEKNIK, 40 (3), 2019, 144}

proses reduksi ukuran partikel $\mathrm{Ca}$ dengan metode grinding menggunakan shaker mill selama 2 jam.

Serbuk logam $\mathrm{Mg}, \mathrm{Zn}$ dan $\mathrm{Ca}$ kemudian digabungkan dengan $\mathrm{CaCO}_{3}$ sebagai foaming agent dengan rasio: $87,5 \mathrm{Mg}-0,5 \mathrm{Ca}-4 \mathrm{Zn}-8 \mathrm{CaCO}_{3} ; 85,5 \mathrm{Mg}-$ $0,5 \mathrm{Ca}-4 \mathrm{Zn}-10 \mathrm{CaCO}_{3}$. Proses milling dilakukan dengan menggunakan shaker mill selama 30 menit agar serbuk paduan $\mathrm{Mg}-\mathrm{Ca}-\mathrm{Zn}-\mathrm{CaCO}_{3}$ menjadi homogen. Proses kompaksi dilakukan dengan mesin uji tekan pada temperatur kamar dengan tekanan $100 \mathrm{MPa}$ selama 2 menit dan $200 \mathrm{MPa}$ selama 3 menit hingga menjadi green compact dengan diameter $10 \mathrm{~mm}$ dan tinggi 10 $\mathrm{mm}$.

Green compact dipanaskan dalam tube furnace pada temperatur sintering 650,675 dan $700{ }^{\circ} \mathrm{C}$ dengan waktu tahan selama 3 jam pada suasana argon. Temperatur sintering ditentukan berdasarkan hasil differential thermal analysis (DTA) dalam paduan $\mathrm{Mg}$ $\mathrm{Zn}-\mathrm{Ca}-\mathrm{CaCO}_{3}$ dan $\mathrm{CaCO}_{3}$ yaitu pada rentang temperatur 599,9- $722{ }^{\circ} \mathrm{C}$ (Andi, 2017).

Struktur yang terbentuk dalam paduan setelah proses sintering dikarakterisasi menggunakan $x$-ray diffraction (XRD) merk Shimadzu XRD-7000. Jenis dan ukuran pori yang dihasilkan dalam paduan setelah proses sintering diamati dengan menggunakan scanning electron microscopy-energy dispersive spectrometry (SEM - EDS) merk JEOL JSM-6390A. Sifat mekanik dapat diketahui melalui uji kompresi sesuai standar ASTM D695-02 dengan alat uji universal testing machine (Shimadzu AGS-10 KN) pada temperatur kamar dengan laju sebesar $10 \mathrm{~mm} / \mathrm{min}$. Pengujian porositas dan densitas menggunakan metode Archimedes sesuai standar ASTM B311-93 yakni menimbang massa sampel di udara dan massa sampel yang dibenamkan di dalam air, kemudian densitas sampel dihitung dengan menggunakan Persamaan 1.

$$
\rho_{b}=\frac{m_{1}}{m_{3}-m_{2}} \times \rho_{\text {air }}
$$

Dimana $\rho_{\mathrm{b}}$ adalah densiti secara teoritis $\left(\mathrm{gr} / \mathrm{cm}^{3}\right), \mathrm{m}_{1}=$ berat kering sampel (gram), $\mathrm{m}_{1}=$ berat sampel dalam air (gram), $\mathrm{m}_{3}=$ berat basah sampel (gram), $\rho_{\text {air }}$ adalah densiti air $\left(\mathrm{gr} / \mathrm{cm}^{3}\right)$.

Untuk menghasilkan porositas, maka setelah diperoleh densitas, digunakan Persamaan 2.

$$
\mu=1-\frac{\rho_{t}}{\rho_{b}} \times 100 \%
$$

Dimana $\mu$ merupakan porositas, $\rho_{\mathrm{b}}$ merupakan densiti basah $\left(\mathrm{gr} / \mathrm{cm}^{3}\right)$, dan $\rho_{\mathrm{t}}$ adalah densiti kering $\left(\mathrm{gr} / \mathrm{cm}^{3}\right)$.

\section{Hasil dan Pembahasan}

\subsection{Hasil Analisis XRD}

Hasil analisis XRD pada $2 \theta=10^{\circ}-90^{\circ}$ untuk paduan $\mathrm{Mg}-4 \mathrm{Zn}-0,5 \mathrm{Ca}-8 \mathrm{CaCO}_{3}$ dan $\mathrm{Mg}-4 \mathrm{Zn}-0,5 \mathrm{Ca}-$ $10 \mathrm{CaCO}_{3}$ dengan temperatur sintering 650, 675 dan $700{ }^{\circ} \mathrm{C}$ ditunjukkan pada Gambar 1a dan 1b. Fasa yang terbentuk dalam kedua komposisi adalah $\mathrm{Mg}, \mathrm{MgO}$, $\mathrm{MgZn}$ dan $\mathrm{Mg}_{2} \mathrm{Ca}$, sedangkan dalam paduan $\mathrm{Mg}-4 \mathrm{Zn}$ $0,5 \mathrm{Ca}-10 \mathrm{CaCO}_{3}$ dihasilkan fasa intermetalik lain yaitu $\mathrm{Ca}_{2} \mathrm{Mg}_{6} \mathrm{Zn}_{3}$. Fasa $\mathrm{Mg}$ terbentuk karena $\mathrm{Mg}$ sebagai logam dasar dalam paduan.
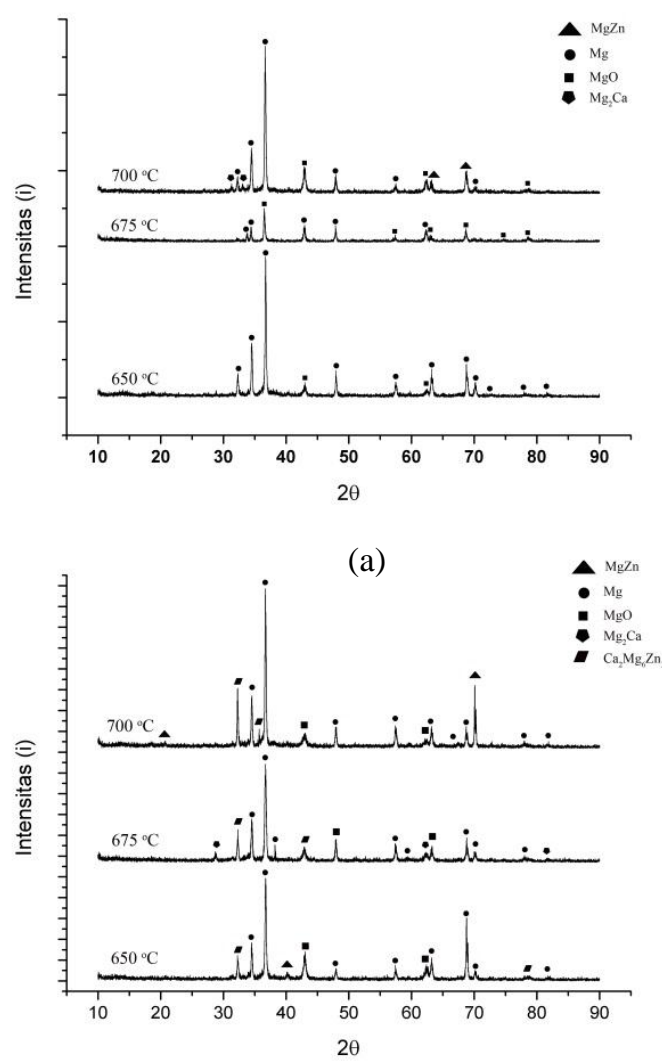

(b)

Gambar 1. Hasil XRD paduan $\mathrm{Mg}-0,5 \mathrm{Ca}-4 \mathrm{Zn}$ pada temperatur sintering 650, 675 dan $700{ }^{\circ} \mathrm{C}$ dengan komposisi foaming agent $\mathrm{CaCO}_{3}$ (\% berat) sebesar; (a) 8 dan (b) 10

Munculnya fasa intermetalik MgZn ketika penambahan komposisi $\mathrm{Zn}>4 \%$ berat, dimana fasa $\mathrm{MgZn}$ mengakibatkan struktur permukaan $\mathrm{Mg}-\mathrm{Zn}-\mathrm{Ca}$ menjadi rapuh dan ketahanan korosi menjadi berkurang.

Fasa kedua $\mathrm{Mg}_{2} \mathrm{Ca}$ bersifat getas dan dapat mengurangi elastisitas paduan $\mathrm{Mg}-\mathrm{Ca}$. Li, Hodgson \& Wen (2011) melakukan penambahan konsentrasi kalsium ke dalam paduan $\mathrm{Mg}-\mathrm{Ca}$ dengan kandungan 0,5 sampai $20 \%$ berat $\mathrm{Ca}$ dimana dihasilkan fasa kedua 


\section{TEKNIK, 40 (3), 2019, 145}

berupa $\mathrm{Mg}_{2} \mathrm{Ca}$ pada batas butir. Menurut laporan (Zhang, Wang dan Geng, 2011), kemunculan fasa intermetalik $\mathrm{Mg}_{2} \mathrm{Ca}$ karena fasa ini akan terbentuk pada penambahan unsur $\mathrm{Ca}>0,5 \%$ berat, fasa intermetalik $\mathrm{Mg}_{2} \mathrm{Ca}$ dapat menurunkan ketahanan korosi pada paduan biner $\mathrm{Mg}-4 \mathrm{Zn}-\mathrm{XCa}$.

$\mathrm{MgO}$ yang terbentuk mengindikasikan bahwa pada proses sintering masih adanya oksigen, fasa $\mathrm{MgO}$ sangat dihindari karena dapat menurunkan ketahanan korosi. Senyawa oksida berupa $\mathrm{MgO}$ tidak beracun pada tubuh, hanya berakibat pada sifat mekanik dari implan, yaitu akan meningkatkan laju korosi dari paduan $\mathrm{Mg}$ (Gonzales $d k k ., 2013$ ).

\subsection{Analisis SEM}

Hasil proses sintering dalam paduan $\mathrm{Mg}$ dengan variasi penambahan foaming agent $\mathrm{CaCO}_{3}$ ditunjukkan dalam Gambar 2 sampai dengan Gambar 4.

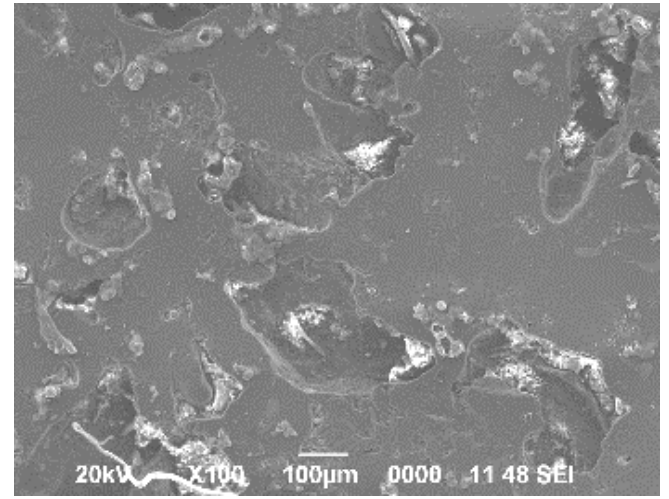

(a)

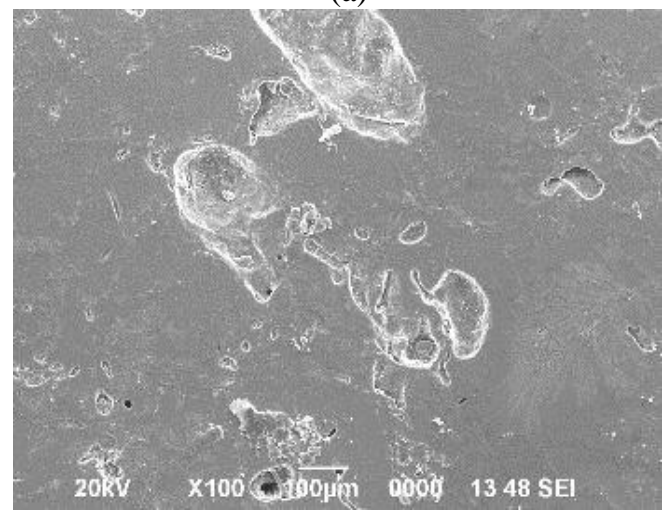

(b)

Gambar 2. Foto struktur mikro hasil SEM dengan temperatur sintering $650{ }^{\circ} \mathrm{C}$ pada paduan $\mathrm{Mg}-\mathrm{Zn}-\mathrm{Ca}$ dengan foaming agent $\mathrm{CaCO}_{3}$ (\% berat) sebesar; (a) 8, dan (b) 10

Foto hasil SEM paduan $\mathrm{Mg}-\mathrm{Zn}-\mathrm{Ca}$ hasil sintering pada $\mathrm{T}$ sebesar $650{ }^{\circ} \mathrm{C}$ dengan penambahan foaming agent $\mathrm{CaCO}_{3} 8$ dan $10 \%$ berat ditunjukkan pada Gambar 2. Struktur yang terbentuk memiliki matriks Mg dengan beberapa pori yang dihasilkan. Pada gambar tersebut teramati bahwa pori yang terbentuk masih berjenis pori tertutup (closed cell) sehingga belum memiliki konektifitas dengan pori-pori lainnya yang sudah terbentuk. Jenis pori tertutup (closed cell) yang terbentuk dalam paduan dapat dibuktikan dengan masih terlihatnya dasar permukaan pada lubang-lubang pori secara visual dalam foto hasil SEM pada Gambar 2. Hasil pengamatan pada Gambar 2a menunjukkan bahwa dengan penambahan $\mathrm{CaCO}_{3} 8 \%$ berat, pori yang terbentuk memiliki ukuran terkecil $20 \mu \mathrm{m}$ dan ukuran terbesar 206,74 $\mu \mathrm{m}$. Pada peningkatan penambahan $\mathrm{CaCO}_{3}$ sebesar $10 \%$ berat, ukuran pori terkecil yang terbentuk adalah 106,62 $\mu \mathrm{m}$, sedangkan ukuran terbesar berkisar $435,22 \mu \mathrm{m}$. Peningkatan temperatur sintering akan meningkatkan ekspansi dari $\mathrm{CaCO}_{3}$. sehingga pada temperatur $675{ }^{\circ} \mathrm{C}$ (Gambar 3), pori yang terbentuk terlihat meningkat dibandingkan pada temperatur $650{ }^{\circ} \mathrm{C}$ (Gambar 2).

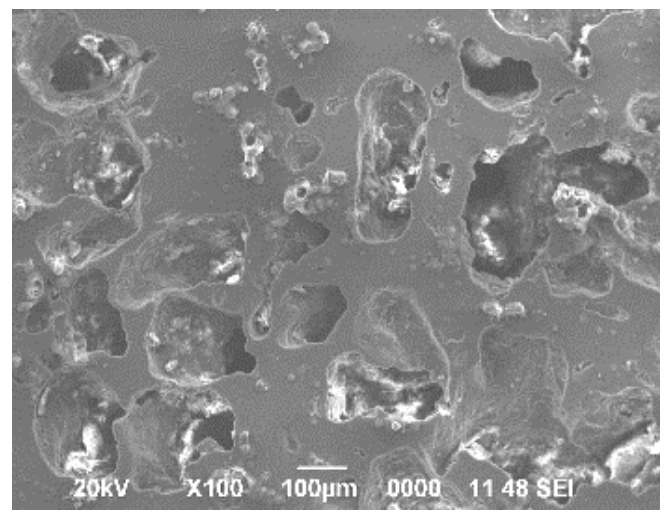

(a)

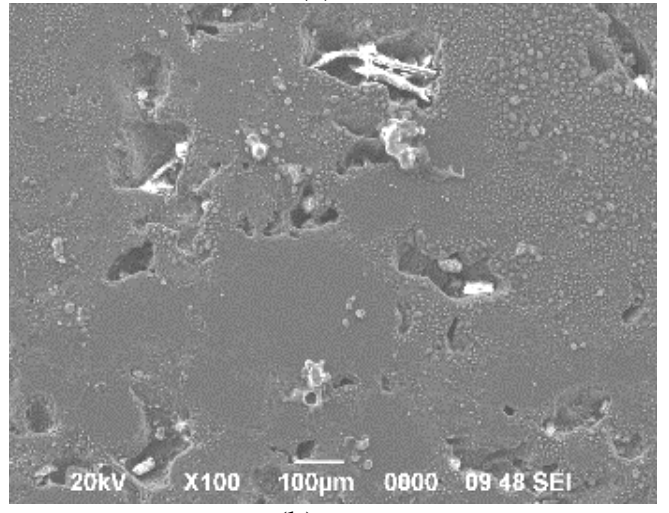

(b)

Gambar 3. Foto struktur mikro hasil SEM dengan temperatur sintering $675{ }^{\circ} \mathrm{C}$ pada paduan $\mathrm{Mg}-\mathrm{Zn}-\mathrm{Ca}$ dengan foaming agent $\mathrm{CaCO}_{3}$ (\% berat) sebesar; (a) 8, dan (b) 10

Gambar 3 menunjukkan foto SEM paduan $\mathrm{Mg}$-Ca$\mathrm{Zn}$ pada temperatur sintering $675{ }^{\circ} \mathrm{C}$. Pada penambahan $8 \%$ berat $\mathrm{CaCO}_{3}$ dalam paduan, teramati pori yang 


\section{TEKNIK, 40 (3), 2019, 146}

terbentuk memiliki ukuran dari 79,92 $\mu$ m sampai dengan $332,66 \mu \mathrm{m}$ (Gambar 3a). Untuk penambahan $10 \%$ berat $\mathrm{CaCO}_{3}$ dalam paduan dengan temperatur sintering $675^{\circ} \mathrm{C}$, ukuran pori yang terbentuk adalah $44,41 \mu \mathrm{m}-$ 271,92 $\mu \mathrm{m}$ (Gambar 3b). Hasil pengamatan terhadap Gambar 3a menunjukkan bahwa pada penambahan $8 \%$ berat $\mathrm{CaCO}_{3}$ dengan temperatur sintering $675{ }^{\circ} \mathrm{C}$, pori yang terbentuk di permukaan sudah cukup homogen bila dibandingkan dengan penambahan $10 \%$ berat $\mathrm{CaCO}_{3}$ pada temperatur sintering yang sama. Peningkatan temperatur sintering akan meningkatkan ekspansi dari $\mathrm{CaCO}_{3}$ sehingga pada temperatur $675{ }^{\circ} \mathrm{C}$ (Gambar 3) secara visual pori yang terbentuk terlihat meningkat dibandingkan temperatur $650{ }^{\circ} \mathrm{C}$ (Gambar 2).

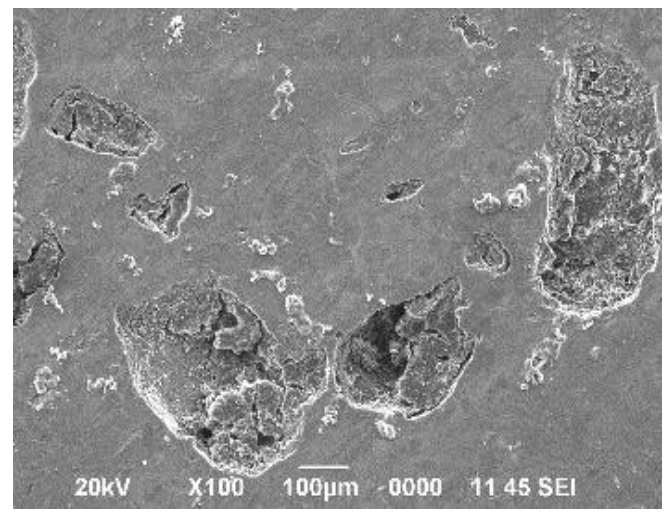

(a)

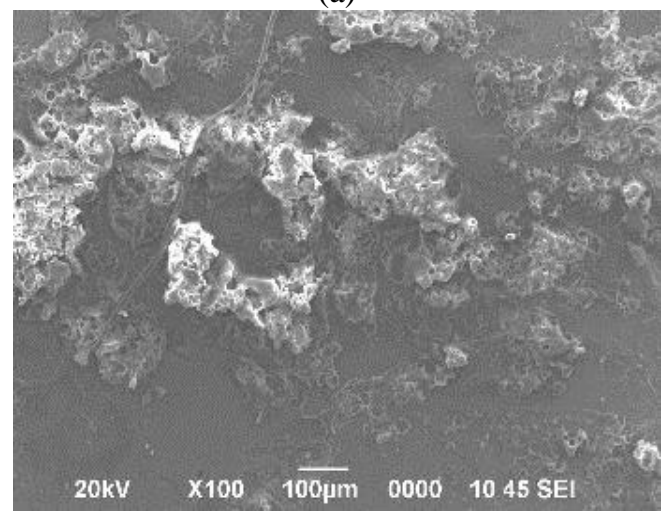

(b)

Gambar 4. Foto struktur mikro hasil SEM dengan temperatur sintering $700{ }^{\circ} \mathrm{C}$ pada paduan $\mathrm{Mg}-\mathrm{Zn}-\mathrm{Ca}$ dengan foaming agent $\mathrm{CaCO}_{3}$ (\% berat) sebesar; (a) 8, dan (b) 10

Gambar 4a dan 4b menunjukkan foto struktur dengan SEM dari paduan $\mathrm{Mg}-0,5 \mathrm{Ca}-4 \mathrm{Zn}$ setelah proses sintering pada temperatur $700{ }^{\circ} \mathrm{C}$ dengan penambahan $\mathrm{CaCO}_{3}$ sebesar 8 dan $10 \%$ berat. Teramati pada Gambar $4 \mathrm{~b}$, pori dengan ukuran lebih kecil terbentuk pada penambahan $10 \%$ berat $\mathrm{CaCO}_{3}$, sedangkan pada penambahan temperatur dan $8 \%$ berat $\mathrm{CaCO}_{3}$, pori yang terbentuk tidak memenuhi permukaan seperti halnya
Gambar 4b, akan tetapi diameter pori yang terbentuk lebih besar. Ukuran pori yang terbentuk pada kondisi ini adalah $70 \mu \mathrm{m}-406,05 \mu \mathrm{m}$ untuk penambahan $\mathrm{CaCO}_{3}$ sebanyak $8 \%$ berat (Gambar 4a), dan ukuran 18,22 $\mu \mathrm{m}-$ $347,64 \mu \mathrm{m}$ untuk penambahan $10 \%$ berat $\mathrm{CaCO}_{3}$ (Gambar 4b).

\subsection{Analisis Sifat Mekanik}

Gambar 5a - 5c menunjukkan persentasi porositas, besarnya densitas dan kekuatan tekan (MPa) dalam paduan $\mathrm{Mg}-0,5 \mathrm{Ca}-4 \mathrm{Zn}$ dengan penambahan foaming agent $\mathrm{CaCO}_{3}$ sebesar 8 dan $10 \%$ berat.

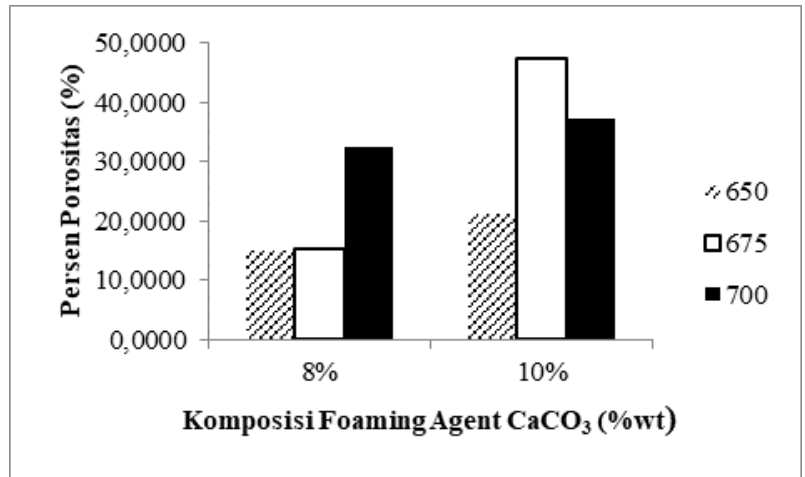

(a)

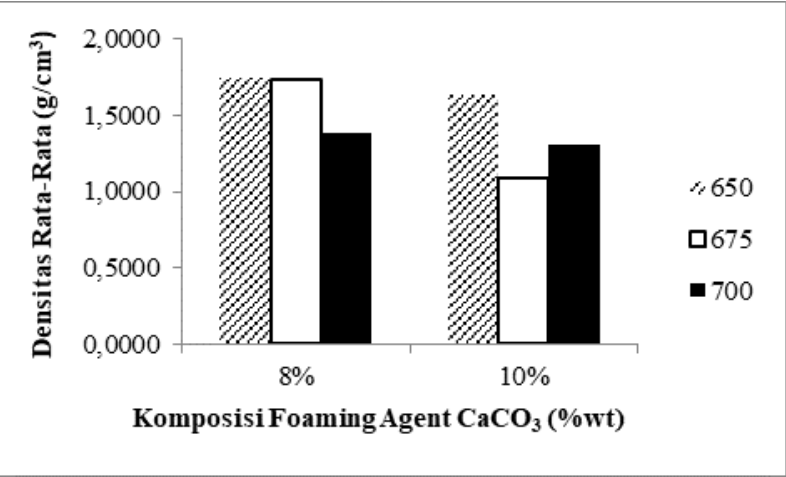

(b)

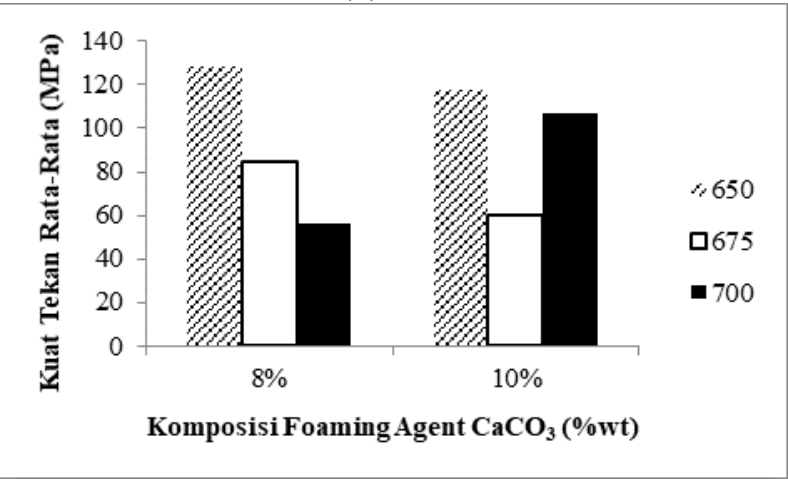

(c)

Gambar 5. Grafik antara komposisi $\mathrm{CaCO}_{3}$ dan temperatur sintering dalam paduan $\mathrm{Mg}-0,5 \mathrm{Ca}-4 \mathrm{Zn}$ untuk 


\section{TEKNIK, 40 (3), 2019, 147}

menghasilkan; (a) porositas (\%), (b) densitas rata-rata $\left(\mathrm{gr} / \mathrm{cm}^{3}\right)$, dan $(\mathrm{c})$ kekuatan tekan $(\mathrm{MPa})$

Berdasarkan grafik hasil uji pada Gambar 5a - 5c, porositas yang dihasilkan dalam paduan pada umumnya meningkat sedangkan densitas dan kekuatan tekan akan semakin menurun seiring dengan meningkatnya penambahan foaming agent $\mathrm{CaCO}_{3}$ dan kenaikan temperatur sintering. Ditegaskan oleh Pulagara, Saini \& Dondapati (2015) dalam penelitiannya menggunakan dolomit, semakin tinggi penambahan persen foaming agent, maka semakin tinggi persen pori yang terbentuk dan semakin rendah nilai densitas yang dihasilkan dalam paduan. Hal ini disebabkan karena foaming agent $\mathrm{CaCO}_{3}$ terdekomposisi menjadi gas $\mathrm{CO}_{2}$ sehingga menyebabkan porositas terbentuk. Semakin banyak foaming agent $\mathrm{CaCO}_{3}$ yang diberikan, maka akan semakin banyak pula $\mathrm{CaCO}_{3}$ yang terdekomposisi menjadi gas $\mathrm{CO}_{2}$. Akan tetapi pada penambahan $10 \%$ berat foaming agent dengan temperatur sintering $675{ }^{\circ} \mathrm{C}$ (Gambar 5), terjadi peningkatan porositas yang dihasilkan bila dibandingkan dengan temperatur sintering $700{ }^{\circ} \mathrm{C}$. Menurut Syafri, Isranuri dan Suprianto (2013), salah satu penyebab lebih rendahnya persentasi porositas yang terbentuk dengan peningkatan temperatur sintering adalah bahwa paduan $\mathrm{Mg}-0,5 \mathrm{Ca}-4 \mathrm{Zn}$ tidak tersinter dengan sempurna, sehingga mempengaruhi proses dispersi antara paduan magnesium dengan foaming agent $\mathrm{CaCO}_{3}$ yng mengakibatkan tidak terjadinya proses pembusaan (foaming) yang sempurna. Ketidak sempurnaan pembusaan menyebabkan penyebaran pori yang tidak merata. Yang $d k k$. (2017) mengemukakan bahwa ketidaksempurnaan dekomposisi foaming agent dikarenakan perbedaan temperatur dekomposisi antara foaming agent $\mathrm{CaCO}_{3}$ dengan temperatur lebur dari magnesium yaitu $650{ }^{\circ} \mathrm{C}$. Porositas terendah terdapat pada paduan $8 \%$ berat $\mathrm{CaCO}_{3}$ (temperatur sinter $650{ }^{\circ} \mathrm{C}$ ) yaitu $15 \%$ dan porositas terbesar terdapat pada $10 \%$ berat $\mathrm{CaCO}_{3}$ (temperatur sinter $675^{\circ} \mathrm{C}$ ) yaitu $47,5 \%$ (Gambar 5a).

Faktor yang mempengaruhi nilai kuat tekan adalah porositas dan temperatur sintering yang berdampak pada sifat mekanik material. Rendahnya kuat tekan pada paduan Mg-0,5Ca-4Zn (Gambar 5c) disebabkan distribusi pori yang tidak merata pada setiap bidang paduan dan ukuran pori yang tidak homogen diakibatkan efek temperatur sintering (Gambar 2, 3 dan 4). Menurut Yang $d k k$. (2017) bahwa semakin besar temperatur sintering maka akan semakin tinggi laju pelepasan gas $\mathrm{CO}$ ke dalam paduan $\mathrm{Mg}-\mathrm{Zn}-\mathrm{Ca}$ yang akan menciptakan pori yang lebih besar, pori yang lebih banyak dan distribusi yang lebih merata. Perbedaan kuat tekan dikarenakan perbedaan komposisi foaming agent dan temperatur sintering. Jika dilihat dari hasil XRD adanya fasa intermetalik $\mathrm{Mg}_{2} \mathrm{Ca}$ dan $\mathrm{Ca}_{2} \mathrm{Mg}_{6} \mathrm{Zn}_{3}$ dapat meningkatkan sifat mekanik dari paduan. Paduan menjadi lebih keras, akan tetapi lebih mudah terkorosi dibandingkan bila fasa $\mathrm{Mg}$ lebih dominan terbentuk dalam paduan. Dapat disimpulkan dari data hasil uji tekan, bahwa semakin tinggi persentase porositas, maka semakin kecil nilai kuat tekan yang diperoleh (Gambar 5a dan 5c). Penambahan $\mathrm{Zn}$ dapat meningkatkan sifat mekanik untuk mengimbangi pori yang terbentuk oleh foaming agent. Meskipun kekuatan tekan paduan $\mathrm{Mg}$ $\mathrm{Zn}-\mathrm{Ca}-\mathrm{CaCO}_{3}$ menurun dengan nilai persentase porositas meningkat, diperkirakan dengan hasil sifat mekanik yang diperoleh dari paduan ini yang berkisar antara $60-128 \mathrm{MPa}$ atau 0,6-0,128 GPa (Gambar 5), maka hasil kekuatan tekan yang diperoleh dibagi dengan regangan yang terjadi, dimungkinkan hasil Young Modulus dari paduan ini akan mendekati sifat mekanik dari tulang cancellous manusia. Yusop dkk. (2012) memaparkan bahwa magnesium memiliki sifat fisik dan sifat mekanik yang mendekati tulang cortical (5-23 GPa) dan tulang cancellous (0,01-0,57 GPa) dibandingkan paduan Ti-6Al-4V (114 GPa) dan baja tahan karat 316L (190 GPa), dimana Young Modulus magnesium paduan berkisar 41-45 GPa.

\section{Kesimpulan}

Analisis porositas paduan logam seluler $\mathrm{Mg}-0,5 \mathrm{Ca}-$ $4 \mathrm{Zn}$ dengan variasi foaming agent $\mathrm{CaCO}_{3}$ sebesar 8 dan $10 \%$ berat dengan temperatur sintering 650, 675 dan 700 ${ }^{\circ} \mathrm{C}$ dan waktu tahan 3 jam telah dilakukan. Tren yang muncul adalah semakin meningkatnya temperatur sintering dan penambahan $\mathrm{CaCO}_{3}$ dalam paduan semakin meningkatkan pori yang terbentuk sehingga menurunkan densitas dan kekuatan tekan dari paduan Mg-0,5Ca-4Zn. Pengamatan dengan SEM menunjukkan ukuran pori terbesar yang terbentuk adalah sebesar $106,62-435,22 \mu \mathrm{m}$ yang dihasilkan dalam paduan $85,5 \mathrm{Mg}-0,5 \mathrm{Ca}-4 \mathrm{Zn}-10 \mathrm{CaCO}_{3}$ pada temperatur sintering $650{ }^{\circ} \mathrm{C}$.

\section{Ucapan Terima Kasih}

Penulis mengucapkan terima kasih kepada Pusat Penelitian Metalurgi dan Material - LIPI yang telah mendanai penelitian ini dari kegiatan Kompetensi Inti Tahun Anggaran 2018.

\section{Daftar Pustaka}

Radha, R., Sreekanth, D. (2017). Insight of magnesium alloys and composites for orthopedic implant applications - a review. Journal of Magnesium and Alloys, 5(3), 286-312.

Sankalp, A., Curtin, J., Duffy, B., Jaiswal, S., (2016). Biodegradable magnesium alloys for orthopaedic applications: A review on corrosion, 


\section{TEKNIK, 40 (3), 2019, 148}

biocompatibility and surface modifications. Journal Materials Science and Engineering C, 68, 948-963.

Zhang, B.P., Wang, Y., Geng, L. (2011). Biomaterials Physics and Chemistry (p. 187), Rijeka: InTech.

Zheng, Y.F., Gu, X.N., Witte, F. (2014). Biodegradable Metals. Journal Material Science and Engineering $F, 77,1-34$.

Xin, Y., Huo, K., Tao, H., Tang, G., Chu, P. K. (2008). Influence of aggressive ions on the degradation behavior of biomedical magnesium alloy in physiological environment. Acta Biomaterialia, 4, 2008-2015.

Seyedraoufi, Z.S., Mirdamadi, Sh. (2013). Synthesis, Microstructure and Mechanical Properties of Porous Mg-Zn Scaffolds. J Mech Behav Biomed Mater., 21, 1-8.

Yang, D., Chen, W., Lu, J., Hu, Z., Feng, Y., Chen, J., Jiang, J., Ma, A., Wang, L., Wang, H. (2017). Fabrication of Cellular Mg Alloy By Gas Release Reaction Via Powder Metallurgi Approach. Metal Powder Report, 72 (2), 124-127.

Kayhan, S.M., Tahmasebifar, A., Evis, Z., Koc, M. (2015). Effect of Manufacturing Conditions on the Mechanical and Corrosion Behavior of Microtectured AZ91D Prepared by Powder Metallurgy. 4M/ICOMM Conference, DOI :10.13140/RG.2.1.3988.8803.

Pulagara, V.N., Saini, S., Dondapati, R. S. (2015). Study of Manufacturing And Mechanical Properties of $\mathrm{Mg}$ - Foam Using Dolomite as the Blowing Agent: A Review. IOP Conference, DOI:10.13140/RG.2.1.4606.2243.

Gonzalez, S., Pellicer, E., Surinach, S., Baro, M.D., Sort, J. (2013). Biodegradable and Mechanical
Integrity of Magnesium and Magnesium Alloys Suitable fot Implants (p. 316-317). InTech. dx.doi.org/10.5772/55584.

Kennedy, A. (2012). Porous Metals and Metals Foams Made from Powder (p. 38). InTech. Manufacturing Division, University of Nottingham, Nottingham. UK. 2012.

Erryani, A., Lestari, F. P., Annur, D., Amal, M.I., Kartika, I. (2017). Microstructure and Mechanical Study of Mg Alloy Foam Based on Mg-Zn-Ca$\mathrm{CaCO}_{3}$ System. IOP Conf. Series; Materials Science and Engineering, 202, 012028.

Andi. (2017). Pengaruh Variasi Komposisi Foaming Agent dan Temperatur Sintering Paduan $\mathrm{MgZnCa}$ dengan Foaming Agent $\mathrm{CaCO}_{3}$ untuk Aplikasi Implan Mampu Luruh. Skripsi. Universitas Sultan Ageng Tirtayasa.

Li, Y., Hodgson, P. D., Wen, C. (2011). The Effect of Calcium and Yttrium Additions on the Microstructure, Mechanical Properties and Biocompatibility of Biodegradable Magnesium Alloys. Journal of Materials Science, 46(2), 365371.

Syafri, P., Isranuri, I., Suprianto. (2013). Studi Pengaruh Magnesium terhadap Kekuatan Impak dan Mikrostruktur Alumunium Foam Menggunakan $3 \% \mathrm{CaCO}_{3}$ sebagai Blowing Agent. Jurnal $e$ Dinamis, 5(1), 23-28.

Yusop, A. H., Bakir, A.A., Shaharom, N.A., Abdul Kadir, M.R., Hermawan, H. (2012). Porous Biodegradable Metals for Hard Tissue Scaffolds: A Review. Int. J. Biomater. Article ID 641430, 10 pages, doi:10.1155/2012/641430. 